\title{
Field margin floral enhancements increase pollinator diversity at the field edge but show no consistent spillover into the crop field: a meta-analysis
}

\author{
JORGE ZAMORANO, ${ }^{1,2}$ (i) IGNASI BARTOMEUS, ${ }^{3}$ (i) AUDREY A. GREZ ${ }^{2}$ (1) and \\ LUCAS ALEJANDRO GARIBALDI ${ }^{4,5}$ (i) ${ }^{1}$ Programa de Doctorado en Ciencias Silvoagropecuarias y \\ Veterinarias, Universidad de Chile, Santiago, Chile, ${ }^{2}$ Facultad de Ciencias Veterinarias y Pecuarias, Universidad de Chile, Santiago, \\ Chile, ${ }^{3}$ Estación Biológica de Doñana (EBD-CSIC), Sevilla, Spain, ${ }^{4}$ Universidad Nacional de Río Negro, Instituto de Investigaciones en \\ Recursos Naturales, Agroecología y Desarrollo Rural, Río Negro, Argentina and ${ }^{5}$ Consejo Nacional de Investigaciones Científicas y \\ Técnicas, Instituto de Investigaciones en Recursos Naturales, Agroecología y Desarrollo Rural, Río Negro, Argentina
}

\begin{abstract}
Conventional intensification of agriculture has reduced the availability of resources for pollinators, reducing their diversity and affecting plant pollination, both in natural habitats and croplands. Field margin floral enhancements such as flower strips or restored field margins could counteract these negative effects.

2. The approaches to assess the success of these management measures generally evaluate separately the pollinator response at the edge and within the crop, as proxies for pollinator conservation and pollination services, respectively.

3. We performed a meta-analysis to understand the influence of field margin floral enhancements on the abundance and richness of pollinators at the edge and within the field, and on crop yield.

4. We estimated 137 effect sizes from 40 studies, all from the northern hemisphere. Overall, the field margin floral enhancements increased the abundance and richness of pollinators at the field edge but had no consistent effect in the interior of the crop fields. Few studies evaluated crop yield, and in these studies no effects were observed.

5. These results suggest that field margin floral enhancements can constitute a positive conservation action for pollinators but not necessarily associated with pollination ecosystem service.
\end{abstract}

Key words. agroecosystem, conservation tool, floral margins, hedgerows, meta-analysis, pollination service.

\section{Introduction}

A large part of the area originally occupied by many temperate and tropical natural terrestrial ecosystems has become agricultural land (Ramankutty et al., 2008) and the expansion and intensification of agriculture have greatly reduced local biodiversity (Foley et al., 2005). This reduction of biodiversity directly affects a plethora of different ecosystem processes, both in the remaining natural habitats and in the crops itself (Tilman et al., 2001; Oliver et al., 2015). For example, agricultural intensification has reduced the availability of resources for pollinators

Correspondence: Jorge Zamorano, Programa de Doctorado en Ciencias Silvoagropecuarias y Veterinarias, Campus Sur, Universidad de Chile, Santiago, Chile. E-mail: jorge.zamorano@upla.cl
(Tscharntke et al., 2005), which has led to a decrease in the abundance and diversity of pollinators in agroecosystems (Goulson et al., 2015). This lack of pollinators in agricultural fields can result in poor pollination, as well as in a reduction in crop yields (Garibaldi et al., 2009). To persist in agricultural habitats, wild pollinators must be able to find suitable nesting and foraging resources (Kremen et al., 2004; M'Gonigle et al., 2015). Because of this, the re-diversification of agricultural areas has been proposed as a mean to strengthen pollination services provided by wild pollinators (Tscharntke et al., 2005; Kremen et al., 2007; Winfree, 2010; Garibaldi et al., 2014). Diversification of agricultural landscapes can take place at many scales, including within crops (e.g., polyculture), field margin floral enhancements (e.g., hedges and wildflower plantations) or landscape features (e.g., increasing natural coverage percentage) (Kremen \& Miles, 2012; Duru et al., 2015). 
The use of field margin floral enhancements is one of the most extended practices to buffer the impact of intensive agriculture and conserve wild pollinators within their natural habitats (Sardiñas \& Kremen, 2015) For example, best management practices recommended to introduce floral margins as additional sources for foraging and refuge for pollinators within monoculture landscapes (Pywell et al., 2011a). In this sense, it has been found that the restoration of hedges increases the richness of pollinators in the edges of the fields (Hannon \& Sisk, 2009; Carvell et al., 2011). Floral field margins are the most common remnants of semi natural vegetation in crops (Marshall \& Moonen, 2002; Boutin et al., 2002; Dover, 2019). These are linear features of trees, shrubs and grasses that surround the crop. They can be remnants of existing vegetation from cleared lands, result from natural dispersal of plants or can be established through direct sowing (Long \& Anderson, 2010). Moreover, a particular action that is gaining traction for habitat restoration in pollinator dependent crops is the use of flower strips, which are typically planted in the marginal areas adjacent to the crop (Wratten et al., 2012; Morandin \& Kremen, 2013b). Among its benefits are pest control, enhancement of the soil fauna, reduced soil erosion, sediment retention, increased biodiversity and air and water quality (Kort et al., 1998; Kleijn et al., 2006; Smith et al., 2008; Whitehouse et al., 2018). In addition, the value of this vegetation has been widely recognised as a habitat for native species of plants, butterflies and birds within agricultural landscapes (Burel, 1996; Maudsley, 2000; Dover et al., 2000; Hinsley \& Bellamy, 2000).

The effects of field margin floral enhancements can be evaluated for different target benefits. For example, several of these assessments focus on pollinator assemblages in the crop edge (Pywell et al., 2006; Haenke et al., 2009; Lye et al., 2009; Potts et al., 2009; Morandin \& Kremen, 2013a; Morandin et al., 2016; Campbell et al., 2017; Wood et al., 2018), while others study pollinator assemblages within fields (Morandin \& Kremen, 2013b; Barbir et al., 2015; Feltham et al., 2015; Sardiñas \& Kremen, 2015; Morandin et al., 2016; Rundlöf et al., 2018). When studying the effects of field margin floral enhancements on pollinating insects at the edge of the field, the information obtained from this approach is mainly related to the conservation of these organisms in agroecosystems, and, on the other hand, when assessing the diversity of pollinators within of crops, the focus is in enhancing the ecosystem services provided (Kremen et al., 2019). Moreover, the characteristics of the edges also vary depending on the management, for example, edges can be restored or unrestored (i.e. sown and pre-existing plants, respectively) (Feber et al., 1996; Blake et al., 2011; Klein et al., 2012; Sardiñas \& Kremen, 2015), and also vary in the type of vegetation, which can range from arboreal vegetation to herbaceous type (Scheper et al., 2015; Williams et al., 2015; Caudill et al., 2017; Garratt et al., 2017).

Such differences could affect the magnitudes of the effects of field margin floral enhancements, both on pollinators and crop yield (Kremen et al., 2019). Hence, it is necessary to evaluate the studies developed so far to determine whether there are differences in the effect of these management measures due to different spatial and ecological approaches, so in this study, we seek to answer through a meta-analysis: What is the effect of field margin floral enhancements on the diversity of pollinators? Are pollinator responses different at the edge and within the field? Do these effects vary depending on the pollinator taxonomic group? And, do field margin floral enhancements affect crop yield?

\section{Materials and methods}

Literature search and study selection. A search of the published literature on the effect of field margin floral enhancements on pollinators was conducted using the Web of Science core collection database available from 1975 to May 2019 for the Electronic Library of Scientific Information program of the National Agency for Research and Development of Chile, which has access to a collection of almost 6000 scientific and technological journals in the English language. We use the combinations pollinat*ANDhedgerowANDcrop, pollinat*ANDfield marginANDcrop, pollinat*ANDhedgerowANDagro*, pollinat*ANDfield marginANDagro*, pollinat*ANDedgeANDcrop, pollinat*ANDedgeANDagro*, pollinat*ANDflower stripANDcrop, pollinat*ANDflower stripANDagro*. From these search criteria, a total of 447 studies were obtained. Additionally, a search was made in the database of Scheper et al. (2013) (71 studies) and Dover (2019) (204 studies), which reviewed studies that evaluate pollinator responses to changes in crop edge vegetation, both reviews did not assess the effect of field margin floral enhancements, but included these studies to evaluate other objectives, such as the influence of agri-environmental schemes.

The inclusion of studies in our meta-analysis was based on the following criteria:

1. A field study that evaluates the effect of field margin floral enhancements on the pollinator diversity on the edge or within the crop.

2. The response variables consider the abundance, richness, visitation rate of pollinators, and/or crop yield.

3. Mean, standard deviation (or standard error) and sample size are reported. For those studies that reported their results only in graphs, data were obtained using DATATHIEF II software (B. Tummers $2006<$ https://datathief.org/>).

4. Includes a comparison between an experimental and a control group. When comparisons were made between more than two treatments, the extreme groups were used for comparison. For example, in studies comparing the diversity of pollinators at different distances from the crop edge, the experimental treatment was the site closest to the edge and the control was the site further away from the edge (three studies) and generally there are no significant differences between the survey distances within the field. In the case that the study was carried out over several years, only the data from the last year were used (seven studies).

Treatments compare always sites with field margin floral enhancement (experimental group) and sites without field margin floral enhancement (control group) (Fig. 1). The control treatments can include fields with edges managed with monofloral strips, edges without hedges or floral strips, and in the case 


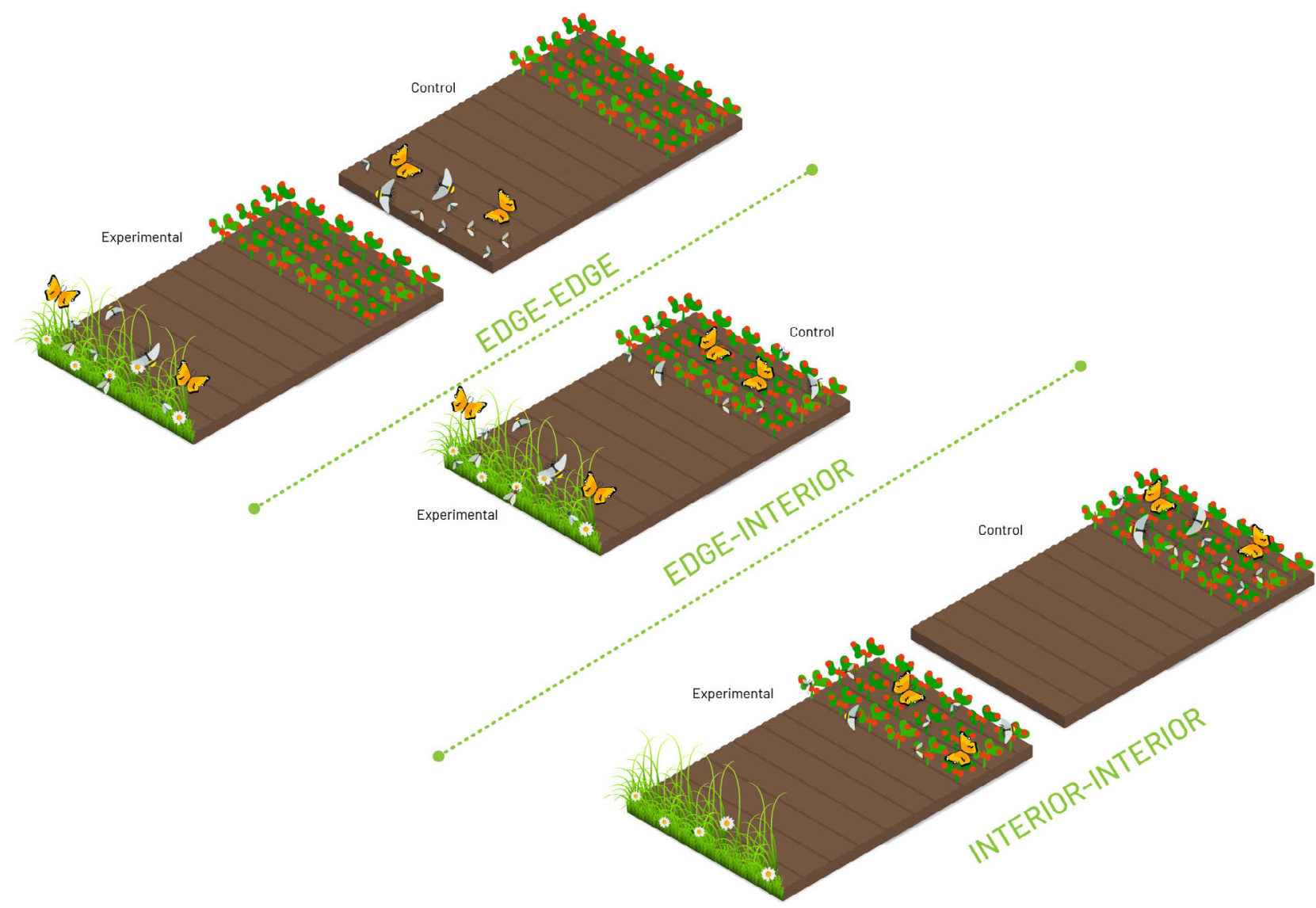

Figure 1. Graphical representation of the three contrast types considered in our meta-analysis to understand the effects of field margin floral enhancements. Edge-edge when crop edges of different fields were compared, edge-interior when the edge of the crop was compared with the inside of the same field, and interior-interior when sites within crops were compared between different fields. The insects depict the sampling locations. [Color figure can be viewed at wileyonlinelibrary.com]

of edge-interior contrast, the interior of the crop with a conventional management. Each study was categorised based on: (i) contrast type: edge-edge (EE), when crop edges of different fields were compared; edge-interior (EI), when the edge of the crop was compared with the inside of the same field, and interior-interior (II) when sites within crops were compared between different fields (Fig. 1 and Table 1). (ii) Edge management: restored (e.g., fields with edges with a mix of sown floral strips or hedgerows restored with native or exotic vegetation) and unrestored (e.g., forest edges) (iii) edge type: edges dominated by herbaceous, arboreal or shrubby vegetation. (iv) Pollinator taxa evaluated: butterflies, bumblebees, honeybees, hoverflies, wild bees (i.e. studies including all apoidea) or other wild pollinators (i.e. studies including all pollinator taxa). The response variables were abundance, species richness and visitation rate for each pollinator taxa and the crop yield (Table 1).

Effect sizes. Mean, standard deviation and sample size for the experimental and control groups of each study were recorded. For each study, the Hedges' $d$ index was calculated as a measure of the effect size. Hedges' $d$ is an estimate of the standardised mean difference between the control and experimental groups that is not biased by small sample sizes and unequal sampling variances (Hedges \& Olkin, 1985). Hedges' $d$ is an index without units that calculates the magnitude of the effect and its direction. The highest effect sizes are those that show large differences between the control and experimental groups. For example, positive $d$ values indicate a tendency to increase the response variables (e.g. abundance of visiting pollinators) in edges with field margin floral enhancements (Borenstein et al., 2009).

\section{Statistical analyses}

For each response variable, a mixed-effects model was carried out using edge management, edge type and pollinator guild as moderators of the effect, except for the crop yield in which a random effect model was used because the analysis does not present moderators due to the low number of studies for this variable, which include only restored edges and herbaceous plants. 
Table 1. Detail of 40 studies used in the meta-analysis, moderators and levels are indicated for the estimation of effect sizes.

\begin{tabular}{|c|c|c|c|c|c|c|c|c|}
\hline Authors and Year & Country & Crops & Contrast & $\begin{array}{l}\text { Survey distance } \\
\text { within field (m) }\end{array}$ & $\begin{array}{l}\text { Edge } \\
\text { management }\end{array}$ & Edge type & $\begin{array}{l}\text { Response } \\
\text { variable }\end{array}$ & Pollinators \\
\hline Feber et al. (1996) & England & $\begin{array}{l}\text { Not } \\
\text { reported }\end{array}$ & $\mathrm{EE}$ & NA & Restored & Herbaceous & $\begin{array}{c}\text { Abundance } \\
\text { Richness }\end{array}$ & Butterflies \\
\hline $\begin{array}{l}\text { De Snoo } \\
\text { et al. (1998) }\end{array}$ & Netherlands & $\begin{array}{l}\text { Potato, } \\
\text { Wheat }\end{array}$ & $\mathrm{EE}$ & NA & Unrestored & Herbaceous & $\begin{array}{c}\text { Abundance } \\
\text { Richness }\end{array}$ & Butterflies \\
\hline Pywell et al. (2005) & England & Cereals & $\mathrm{EE}$ & NA & Unrestored & Herbaceous & $\begin{array}{c}\text { Abundance } \\
\text { Richness }\end{array}$ & Bumblebees \\
\hline Pywell et al. (2006) & England & Cereals & $\mathrm{EE}$ & NA & Unrestored & Herbaceous & $\begin{array}{c}\text { Abundance } \\
\text { Richness }\end{array}$ & Bumblebees \\
\hline \multirow[t]{2}{*}{$\begin{array}{l}\text { Haenke } \\
\text { et al. (2009) }\end{array}$} & \multirow[t]{2}{*}{ Germany } & \multirow[t]{2}{*}{ Wheat } & $\mathrm{EE}$ & NA & \multirow[t]{2}{*}{ Unrestored } & \multirow[t]{2}{*}{ Herbaceous } & \multirow[t]{2}{*}{$\begin{array}{c}\text { Abundance } \\
\text { Richness }\end{array}$} & \multirow[t]{2}{*}{ Hoverflies } \\
\hline & & & II & 6 & & & & \\
\hline \multirow[t]{2}{*}{$\begin{array}{l}\text { Hannon and } \\
\text { Sisk (2009)) }\end{array}$} & \multirow[t]{2}{*}{ USA } & Alfalfa & EI & $\begin{array}{l}\text { Between } 400 \text { and } \\
600\end{array}$ & Unrestored & Arboreal & Abundance & \multirow[t]{2}{*}{ Wild bees } \\
\hline & & $\begin{array}{l}\text { Fescue } \\
\text { Sorghum }\end{array}$ & & & & Shrubs & Richness & \\
\hline Lye et al. (2009) & Scotland & Grasses & $\mathrm{EE}$ & NA & Unrestored & $\begin{array}{l}\text { Herbaceous } \\
\text { Shrubs }\end{array}$ & Abundance & Bumblebees \\
\hline $\begin{array}{l}\text { Merckx } \\
\text { et al. (2009). }\end{array}$ & England & $\begin{array}{l}\text { Not } \\
\text { reported }\end{array}$ & $\mathrm{EE}$ & NA & Unrestored & Arboreal & Abundance & Butterflies \\
\hline Potts et al. (2009). & England & Grasses & $\mathrm{EE}$ & NA & Restored & $\begin{array}{l}\text { Herbaceous } \\
\text { Herbaceous }\end{array}$ & $\begin{array}{l}\text { Abundance } \\
\text { Richness }\end{array}$ & $\begin{array}{l}\text { Bumblebees } \\
\text { Butterflies }\end{array}$ \\
\hline $\begin{array}{l}\text { Holzschuh } \\
\text { et al. (2010) }\end{array}$ & Germany & Wheat & $\mathrm{EE}$ & NA & Unrestored & Herbaceous & Richness & Wild bees \\
\hline Blake et al. (2011) & England & $\begin{array}{l}\text { Barley } \\
\text { Beans } \\
\text { Oilseed } \\
\text { rape } \\
\text { Rye } \\
\text { Wheat }\end{array}$ & $\begin{array}{l}\mathrm{EI} \\
\mathrm{EE}\end{array}$ & $\begin{array}{l}\text { NR } \\
\text { NA }\end{array}$ & Restored & Herbaceous & $\begin{array}{l}\text { Abundance } \\
\text { Richness }\end{array}$ & Butterflies \\
\hline $\begin{array}{l}\text { Pywell } \\
\text { et al. (2011b) }\end{array}$ & England & $\begin{array}{c}\text { Oilseed } \\
\text { rape } \\
\text { Wheat }\end{array}$ & $\mathrm{EE}$ & NA & Restored & Herbaceous & $\begin{array}{l}\text { Abundance } \\
\text { Richness }\end{array}$ & $\begin{array}{l}\text { Wild } \\
\text { pollinators }\end{array}$ \\
\hline $\begin{array}{l}\text { Walton and } \\
\text { Isaacs (2011) }\end{array}$ & USA & Blueberry & $\mathrm{EE}$ & NA & Restored & Herbaceous & Abundance & Hoverflies \\
\hline Klein et al. (2012) & USA & Almonds & EI & $50-110$ & Unrestored & Shrubs & Visit rate & $\begin{array}{l}\text { Wild bees } \\
\text { Honeybees } \\
\text { Hoverflies } \\
\text { Wild bees }\end{array}$ \\
\hline $\begin{array}{l}\text { Morandin and } \\
\text { Kremen (2013a) }\end{array}$ & USA & Alfalfa & $\mathrm{EE}$ & NA & Restored & Shrubs & Abundance & Wild bees \\
\hline & & $\begin{array}{l}\text { Tomato } \\
\text { Wheat }\end{array}$ & & & & & Richness & \\
\hline Morandin and & USA & Tomato & II & $10-100-200^{*}$ & Restored & Shrubs & Abundance & Honeybees \\
\hline & & & $\mathrm{EE}$ & NA & & & Richness & $\begin{array}{l}\text { Hoverflies } \\
\text { Wild bees }\end{array}$ \\
\hline $\begin{array}{l}\text { Blaauw and } \\
\text { Isaacs (2014) }\end{array}$ & USA & Blueberry & II & 15 & Restored & Herbaceous & Visit rate & Honeybees \\
\hline & & & & & & & Yield & $\begin{array}{l}\text { Hoverflies } \\
\text { Wild bees }\end{array}$ \\
\hline Barbir et al. (2015) & Spain & Coriander & $\begin{array}{l}\text { EE } \\
\text { II }\end{array}$ & $\begin{array}{l}\text { NA } \\
\text { NR }\end{array}$ & Restored & Herbaceous & $\begin{array}{l}\text { Visit rate } \\
\text { Yield }\end{array}$ & $\begin{array}{l}\text { Hoverflies } \\
\text { Wild bees }\end{array}$ \\
\hline & Scotland & Strawberry & II & 100 & Restored & Herbaceous & Abundance & \\
\hline
\end{tabular}


Table 1. (continued)

\begin{tabular}{|c|c|c|c|c|c|c|c|c|}
\hline Authors and Year & Country & Crops & Contrast & $\begin{array}{l}\text { Survey distance } \\
\text { within field (m) }\end{array}$ & $\begin{array}{l}\text { Edge } \\
\text { management }\end{array}$ & Edge type & $\begin{array}{l}\text { Response } \\
\text { variable }\end{array}$ & Pollinators \\
\hline $\begin{array}{l}\text { Feltham } \\
\text { et al. (2015) }\end{array}$ & & & & & & & & $\begin{array}{l}\text { Wild } \\
\text { pollinators }\end{array}$ \\
\hline Pywell et al. (2015) & England & $\begin{array}{l}\text { Beans } \\
\text { Oilseed } \\
\text { rape }\end{array}$ & $\mathrm{EE}$ & NA & Restored & Herbaceous & Abundance & Wild bees \\
\hline \multirow[t]{2}{*}{$\begin{array}{l}\text { Sardiñas and } \\
\text { Kremen (2015) }\end{array}$} & USA & $\begin{array}{l}\text { Wheat } \\
\text { Sunflower }\end{array}$ & $\mathrm{EE}$ & NA & Unrestored & Arboreal & Abundance & Wild bees \\
\hline & & & EI & $\begin{array}{l}10-50-100-200 \\
10-50-100-200\end{array}$ & & & Richness & \\
\hline \multirow[t]{2}{*}{$\begin{array}{l}\text { Scheper } \\
\text { et al. }(2015)\end{array}$} & England & $\begin{array}{l}\text { Not } \\
\text { reported }\end{array}$ & $\begin{array}{l}11 \\
\mathrm{EE}\end{array}$ & $\begin{array}{l}10-50-100-200 \\
\text { NA }\end{array}$ & Restored & Herbaceous & Abundance & Bumblebees \\
\hline & $\begin{array}{l}\text { Germany } \\
\text { Netherlands } \\
\text { Sweden }\end{array}$ & & & & & & & Wild bees \\
\hline $\begin{array}{l}\text { Williams } \\
\text { et al. }(2015)\end{array}$ & USA & $\begin{array}{l}\text { Not } \\
\text { reported }\end{array}$ & $\mathrm{EE}$ & NA & Restored & Herbaceous & Richness & Wild bees \\
\hline $\begin{array}{l}\text { Morandin } \\
\text { et al. }(2016)\end{array}$ & USA & Tomato & II & $10-100-200$ & Unrestored & Shrubs & Visit rate & Honeybees \\
\hline $\begin{array}{l}\text { Sardiñas } \\
\text { et al. (2016) }\end{array}$ & USA & Sunflower & $\mathrm{EE}$ & NA & Unrestored & Shrubs & Abundance & $\begin{array}{l}\text { Wild bees } \\
\text { Wild bees }\end{array}$ \\
\hline Balzan (2017) & Malta & Tomato & $\begin{array}{l}\text { II } \\
\text { EI }\end{array}$ & $\begin{array}{l}50-100-150-200^{*} \\
\text { NR }\end{array}$ & Restored & Herbaceous & $\begin{array}{l}\text { Abundance } \\
\text { Yield }\end{array}$ & Wild bees \\
\hline \multirow[t]{3}{*}{$\begin{array}{l}\text { Campbell } \\
\text { et al. (2017) }\end{array}$} & England & Apple & $\mathrm{EE}$ & NA & Restored & Herbaceous & Abundance & Bumblebees \\
\hline & & & & & & & Richness & Wild bees \\
\hline & & & & & & & Yield & $\begin{array}{l}\text { Wild } \\
\text { pollinators }\end{array}$ \\
\hline \multirow[t]{2}{*}{$\begin{array}{l}\text { Caudill } \\
\text { et al. (2017) }\end{array}$} & Costa Rica & Coffee & EI & $50-150^{*}$ & Unrestored & Arboreal & Abundance & Honeybees \\
\hline & & & & & & & $\begin{array}{l}\text { Richness } \\
\text { Visit rate }\end{array}$ & Wild bees \\
\hline Garratt et al. (2017) & England & Wheat & $\mathrm{EE}$ & NA & Unrestored & Arboreal & Abundance & Bumblebees \\
\hline $\begin{array}{l}\text { Dainese } \\
\text { et al. }(2017)\end{array}$ & Italy & Wheat & $\mathrm{EE}$ & NA & Unrestored & Arboreal & Abundance & Butterflies \\
\hline $\begin{array}{l}\text { McKechnie } \\
\text { et al. }(2017)\end{array}$ & Canada & Blueberry & $\mathrm{EE}$ & NA & Unrestored & Arboreal & Visit rate & $\begin{array}{l}\text { Wild bees } \\
\text { Wild bees }\end{array}$ \\
\hline $\begin{array}{l}\text { Tangtorwongsakul } \\
\text { et al. (2018) }\end{array}$ & Thailand & Mango & EI & NR & Unrestored & Arboreal & Abundance & Wild bees \\
\hline $\begin{array}{l}\text { Venturini } \\
\text { et al. (2017) }\end{array}$ & USA & Blueberry & $\mathrm{EE}$ & NA & Restored & Herbaceous & $\begin{array}{l}\text { Richness } \\
\text { Visit rate }\end{array}$ & Wild bees \\
\hline Amy et al. (2018) & Belgium & Wheat & $\mathrm{EE}$ & NA & Restored & Herbaceous & $\begin{array}{l}\text { Yield } \\
\text { Abundance } \\
\text { Richness }\end{array}$ & $\begin{array}{l}\text { Hoverflies } \\
\text { Wild bees }\end{array}$ \\
\hline Buhk et al. (2018) & Germany & $\begin{array}{l}\text { Cereals } \\
\text { Maize }\end{array}$ & $\mathrm{EE}$ & NA & Restored & Herbaceous & $\begin{array}{l}\text { Richness } \\
\text { Abundance }\end{array}$ & Wild bees \\
\hline Ganser et al. (2018) & Switzerland & Strawberry & EI & 80 & Restored & Herbaceous & $\begin{array}{l}\text { Abundance } \\
\text { Richness } \\
\text { Yield }\end{array}$ & $\begin{array}{l}\text { Bumblebees } \\
\text { Honeybees } \\
\text { Hoverflies } \\
\text { Wild bees }\end{array}$ \\
\hline $\begin{array}{l}\text { Pfiffner } \\
\text { et al. (2018) }\end{array}$ & Switzerland & Cereals & EI & 30 & Restored & Herbaceous & Abundance & Wild bees \\
\hline
\end{tabular}


Table 1. (continued)

\begin{tabular}{|c|c|c|c|c|c|c|c|c|}
\hline Authors and Year & Country & Crops & Contrast & $\begin{array}{l}\text { Survey distance } \\
\text { within field (m) }\end{array}$ & $\begin{array}{l}\text { Edge } \\
\text { management }\end{array}$ & Edge type & $\begin{array}{l}\text { Response } \\
\text { variable }\end{array}$ & Pollinators \\
\hline \multirow{3}{*}{$\begin{array}{l}\text { Rundlöf } \\
\text { et al. (2018) }\end{array}$} & Sweden & Red clover & $\mathrm{EE}$ & NA & Restored & Herbaceous & $\begin{array}{l}\text { Richness } \\
\text { Abundance }\end{array}$ & Bumblebees \\
\hline & & & EI & Between 8 and 100 & & & Richness & Honeybees \\
\hline & & & II & Between 8 and 100 & & & Yield & \\
\hline \multirow[t]{2}{*}{ Wood et al. (2018) } & USA & Cherry & $\mathrm{EE}$ & NA & Restored & Herbaceous & Abundance & Wild bees \\
\hline & & Blueberry & II & 100 & & & Richness & \\
\hline \multirow[t]{4}{*}{ Knapp et al. (2019) } & England & Courgette & EI & 25 & Unrestored & Herbaceous & Abundance & Bumblebees \\
\hline & & & & & & & & Honeybees \\
\hline & & & & & & & & Hoverflies \\
\hline & & & & & & & & Wild bees \\
\hline
\end{tabular}

The descriptions EE: edge-edge, EI: edge-interior and II: interior-interior are indicated for the contrast in pollinator survey. For survey distance within field, descriptions are indicated NA: Not applicable; NR: Not reported; asterisk indicates studies where maximum survey distance selection was made.

Analyses were run independently for each type of contrast (i.e. edge-edge, edge-interior and interior-interior) and the effect size was estimated for the different levels within each moderator. The models were adjusted using the estimate of maximum restricted likelihood (Koricheva et al., 2013).

Omnibus $(Q M)$ tests of individual moderators were performed to determine the heterogeneity of the effect sizes between the levels of each moderator (e.g. edge management levels). Furthermore, to explore the possibility of publication bias, funnel plots (scatter plots of effect sizes against a measure of their variance) were constructed to determine whether the reported studies were unbalanced (Koricheva et al., 2013). A publication bias towards significant results would create an asymmetric funnel, which generally lacks small studies with no significant effects. In addition, a rank correlation test for funnel plot asymmetry was applied to examine whether the observed results and corresponding sampling variations were correlated (Begg \& Mazumdar, 1994). A high correlation would indicate that the funnel chart is asymmetric, which would indicate a publication bias. All analyses and graphs were performed with the metafor package (Viechtbauer, 2010) through $\mathrm{R}$ version 3.4.4 (R Development Core Team, 2018).

\section{Results}

A total of 40 articles fulfilled our inclusion criteria (Table 1). From those, 137 effect sizes were obtained, which were distributed in 71 for the EE, 39 for EI and 27 for II contrasts. All studies were conducted in the northern hemisphere, with USA and England (12 studies each) being the main countries that have evaluated the questions associated with the conditions proposed in this meta-analysis. These studies were carried out between the years 1996 and 2019, most of them in the last decade, and were performed in 24 types of crops, more frequently in wheat (Triticum aestivum L.) and flowering crops such as blueberries (Vaccinium angustifolium Ait.), oilseed rape (Brassica napus L.) and tomatoes (Solanum lycopersicum L.) (Table 1).

Only in the EE contrast, there was a clear overall positive estimated effect size of field margin floral enhancements for both abundance and richness of pollinators (Fig. 2). In this contrast, both for abundance and richness the heterogeneity test indicates differences between the levels of each proposed moderator (Table 2). The abundance of pollinators is the response variable with the highest number of cases of this entire review $(n=40)$. Restored edges and with the presence of herbaceous plants are those that present the greatest abundance and richness of pollinators on the edge, mainly for hoverflies (abundance-richness) and wild bees (richness). The estimated effect size for both EI and II contrasts is not significant for the set of evaluated moderators (Fig. 2). However, it is worth noting that in the EI contrast, we observe consistent positive effect sizes for pollinator abundance where field margin floral enhancements is restored with herbaceous plants, and for pollinator richness for both restored and unrestored sites, for arboreal and herbaceous edges, and for wild bees (Fig. 2).

The response in pollinator visitation rate did not have an adequate number of cases to perform an analysis for each moderator in each contrast, so only the type of contrast was used as a moderator in the estimation of the effect size. None of the contrasts present significant effect sizes (EE: $d=-0.58 ; 95 \% \mathrm{CI}=-2.19,1.02$; $P=0.47 ; n=4$; EI: $d=0.77 ; 95 \% \mathrm{CI}=-0.37,1.92 ; P=0.18$; $n=6$; and II: $d=0.43$; 95\% CI $=-0.65,1.51 ; P=0.43 ; n=8$ ). Crop yield had only eight cases, which had a restored edge management with herbaceous plants, not having a significant effect size $(d=0.46 ; 95 \% \mathrm{CI}=-0.06,0.99 ; P=0.08)$.

Publication bias inferred through funnel plot only shows asymmetry in effect sizes for both abundance and richness in the EE contrast (Fig. 3a,d). This coincides with the significant associations of the test of rank correlation. This indicates a bias in publications primarily with positive effect sizes and larger standard errors (i.e. low sample size) in this contrast; however, the strong positive response of the visiting pollinators at the crop edge could also be causing an asymmetry in the analysis.

\section{Discussion}

Studies on the effect of field margin floral enhancements on pollinators have focused primarily on assessing the diversity of 


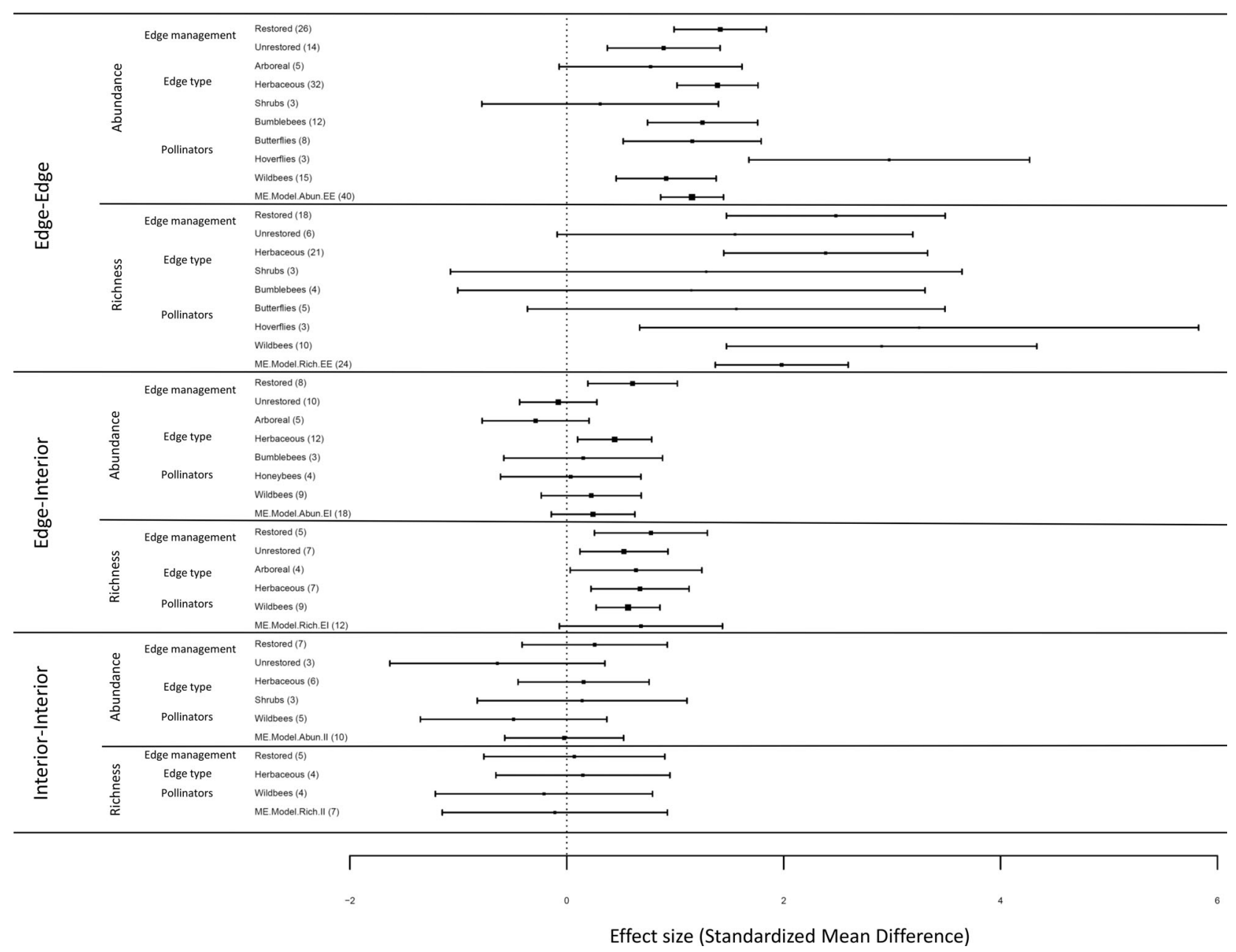

Figure 2. Effect of field margin floral enhancements on the abundance and richness of pollinators response in the edge-edge, edge-interior and interiorinterior contrasts. Forest plot shows the effect size (Hedge's $d$ ) and an estimated 95\% CI of a mixed effects model for each moderator and the mean effect size for all moderators for pollinators abundance and richness in each contrast. The number of cases for the levels of each moderator is indicated in parentheses.

Table 2. Omnibus test for heterogeneity of moderators of effect sizes for the different levels in each contrast.

\begin{tabular}{|c|c|c|c|c|c|c|c|}
\hline \multirow[b]{2}{*}{ Contrast } & \multirow[b]{2}{*}{ Moderators } & \multicolumn{3}{|c|}{ Abundance } & \multicolumn{3}{|c|}{ Richness } \\
\hline & & df & $Q M$ & $P$ & df & $Q M$ & $P$ \\
\hline \multirow[t]{3}{*}{ Edge-Edge } & Edge management & 2 & 53.77 & $<0.0001$ & 2 & 26.67 & $<0.0001$ \\
\hline & Edge type & 3 & 56.79 & $<0.0001$ & 2 & 25.91 & $<0.0001$ \\
\hline & Pollinators & 6 & 80.32 & $<0.0001$ & 5 & 26.93 & $<0.0001$ \\
\hline \multirow[t]{3}{*}{ Edge-Interior } & Edge management & 2 & 8.47 & 0.0145 & 2 & 15.02 & 0.0005 \\
\hline & Edge type & 3 & 8.13 & 0.0432 & 3 & 13.09 & 0.004 \\
\hline & Pollinators & 4 & 3.67 & 0.452 & 3 & 26.04 & $<0.0001$ \\
\hline \multirow[t]{3}{*}{ Interior-Interior } & Edge management & 2 & 2.17 & 0.337 & 2 & 0.52 & 0.77 \\
\hline & Edge type & 3 & 5.11 & 0.163 & 3 & 2.04 & 0.563 \\
\hline & Pollinators & 5 & 4.65 & 0.459 & 3 & 1.05 & 0.787 \\
\hline
\end{tabular}

pollinators at the edge, and fewer efforts have been done trying to understand how these management tools affect pollinators within the field and ultimately, crop yield. Studies with edge- edge contrast sought mainly to determine the ability of edge vegetation to generate resources for visiting pollinators, e.g. in bees, these translate into food and nesting sites (Kremen et al., 2004).

(C) 2020 Royal Entomological Society, Insect Conservation and Diversity, doi: 10.1111/icad.12454 

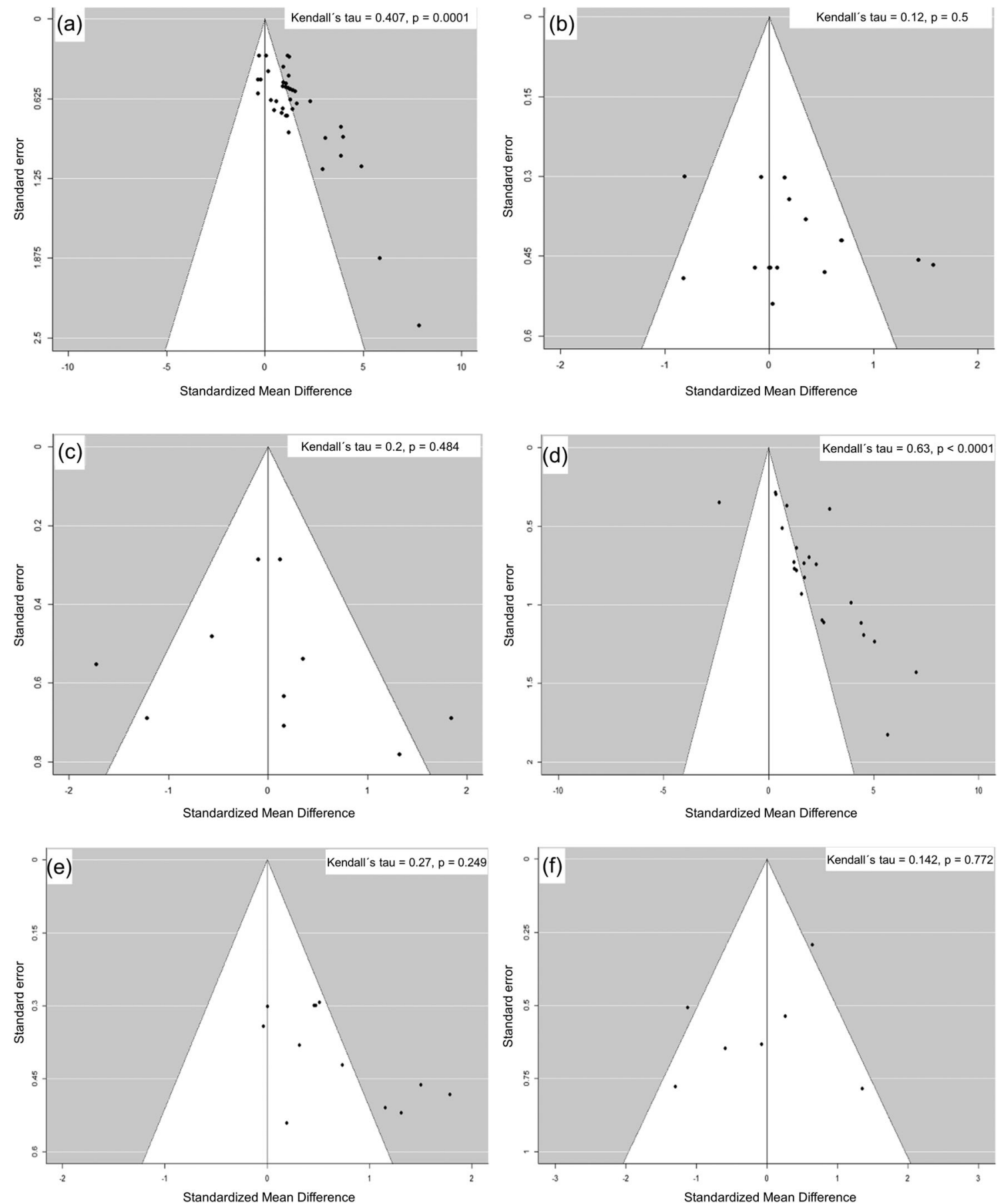

Figure 3. Funnel plot of the individual studies grouped by a: edge-edge abundance; b: edge-interior abundance; c: interior-interior abundance; d: edgeedge richness; e: edge-interior richness; F: interior-interior richness. Results for rank correlation test for funnel plot asymmetry are reported.

This evaluation does not allow to identify the possible spillover of insects from the edge towards the interior of the field. It only allows to determine whether this vegetation works as a conservation tool due to the attraction and permanence of potential pollinators at the edges of the field (Kremen et al., 2019).
In this review, it was observed that the edge management tools that caused an increase in the abundance and richness of pollinators correspond to the management with restored edges and herbaceous plants, particularly in the case of hoverflies and wild bees. This is in agreement with studies that have also shown that 
peripheral areas around crops that contain varied species of wild flowers have positive effects on the abundance and diversity of many insect pollinators, such as honeybees, bumblebees, butterflies, hoverflies and other diptera insects (Lagerlöf et al., 1992; Carreck \& Williams, 1997; Cheesman, 1998; Bäckman \& Tiainen, 2002; Croxton et al., 2005), mainly associated herbaceous plants (Prys-Jones \& Corbet, 1991; Fussell \& Corbet, 1992; Mader et al., 2011) and restored edges (Morandin et al., 2016; Kremen et al., 2019). These edge management techniques are associated with an increase in floral diversity generating an increase in the supply of resources for pollinators, potentially allowing an increase in pollinators in the area (Carvell et al., 2004; Pywell et al., 2005; Greenleaf \& Kremen, 2006; Winfree et al., 2008).

Two hypotheses have been proposed regarding the effect of field margin floral enhancements (e.g., hedgerows) on the pollinator communities visiting the crops (Kremen et al., 2019). On the one hand, we can expect an 'exporter' effect (i.e., spillover) of pollinators from the edge into the crop (Morandin \& Kremen, 2013b; M'Gonigle et al., 2015), and on the other hand, a pollinator 'concentrator' effect on the edge (i.e., pollinators are concentrated in the crop edges with greater foraging resources) (Kleijn et al., 2018; Kremen et al., 2019). This contrasting hypothesis may explain the positive and negative effects documented in the analysis of pollinators visiting the crop. In the case of studies with edge-interior contrast, where the comparison was made between the edge and the interior of the same field (i.e., interior as the control), there is a positive effect for several levels of the moderators mainly on the pollinator richness responses (i.e., greater richness in the edge). This would be giving account of a possible pollinator concentrating effect in these studies, i.e., there is an absence of spillover, so that the field margin floral enhancements would work only as a pollinator conservation tool at the field edge (Kremen et al., 2019). Although this evaluation could show a possible 'concentrator' effect of pollinators, it is necessary to directly elucidate the absence of spillover (e.g. with insect marking), since it is possible that a change in abundance and richness within the field could be both independent as parallel to the changes in the edge, after the field margin floral enhancements.

In the case of the interior-interior design, it is the one that would specifically determine the effect of the edge enhancement on the diversity of pollinators within the field (Morandin et al., 2016). For this contrast, the results indicate that there is heterogeneity in responses when comparing sites with and without field margin floral enhancements, although the number of cases for this contrast is low. Overall, our results suggest a possible neutral effect of field margin floral enhancements on the pollination service in the crops included in this review, consistent with the idea that the edges would be functioning as pollinator attractors and concentrators, but not demonstrating the spillover towards the crop and the consequent ecosystem service delivery (Sardiñas \& Kremen, 2015; Sardiñas et al., 2016; Dainese et al., 2017). However, it is important to consider that the effect of field margin floral enhancements on pollinators within the crop may require time, as pollinator populations fluctuate from year to year and it could take time for them to colonise new habitats and build up larger population sizes (Williams et al., 2001). For example, Blaauw and Isaacs (2014) observed that in wild bees and hoverflies the visitation rate of these began to increase within the crop after the third year of the field margin floral enhancements, so that these populations would be depending on the abundance of the vegetation of previous years. The reviewed papers generally test edges with less than 3 years, opening the door to find more consistent effects when analysed over longer time periods. On the other hand, several edgeinterior and interior-interior studies present different sampling distances towards the interior of the field and in three of them we apply maximum survey distance selection (Table 1); however, in these last studies, the sampling sites in the interior of the crop, there are no significant differences in the visit of pollinators (Morandin \& Kremen, 2013a,b; Sardiñas et al., 2016; Caudill et al., 2017), so the response is constant within the crop. Therefore, we consider that, despite this variability of sampling distances within the fields, the results allow us to determine a no consistent pollinator spillover to crops.

The results for crop yield have no effect in the eight cases included, which is consistent with some of the studies analysed in the review by Kremen et al. (2019) and with the results by Albrecht et al. (2020), but opposed to studies conducted in oilseed rape where pollinator diversity and crop yield increase, the latter due to the interaction between semi-natural landscapes with the effect of the edge vegetation (Haenke et al., 2014; Sutter et al., 2018). It is possible that a set of other factors, such as the type of crop, the composition and heterogeneity of the surrounding landscapes, the size of the edges and their distance towards the interior of the fields, could be affecting the relationship between edge management, pollinators and yield. Albrecht et al. (2020) determined in a synthesis, results similar to those of this study, where they found that the pollination service increases in sites with enhanced field margins, but this effect only occurs adjacent to the edge and with the absence of effect on crop yield. This could be due to different crop management practices (Bartomeus et al., 2015; Gagic et al., 2017) in addition to the landscape context (Dainese et al., 2017), which would be generating variability in the responses of crop production. Further studies need to isolate these factors to understand the effects of edge management on crop yield (Mwangi et al., 2012; Sardiñas \& Kremen, 2015; Morandin et al., 2016).

An important finding of our review is that most of the identified studies have been conducted almost exclusively in the northern hemisphere, with greater prominence of USA and Europe. This result stress the importance of expanding efforts to other regions where to implement and evaluate these tools of biodiversity management and where information on these forms of crop management is still lacking. The situation elsewhere is different from the European context where the application of agrienvironmental schemes has made a greater progress in the use of these management tools.

In summary, there is a set of gaps in the knowledge about the use of field margin floral enhancements as a biodiversity management tool in agroecosystems, with most studies evaluating the use of these tools with pollinator conservation purposes in mind, but very few studies addressing pollination services delivered and yield. Under the current global decline in pollinator populations, it is urgent to advance in the understanding and identification of the factors that modulate the relationship 
between the management of crop edges and pollinators in order to enhance their conservation and ecosystem services in productive environments.

\section{Acknowledgements}

J.Z. thanks the ANID grant 21171360 and the Doctorado en Ciencias Silvoagropecuarias y Veterinarias of the Universidad de Chile for the financial support, J.Z. and A.A.G. thanks FONDECYT 1180533 for your partial support, L.A.G. thanks Agencia Nacional de Promoción Científica y Tecnológica (PICT 2015-2333, PICT-2018-00941), Universidad Nacional de Río Negro (PI 40-B-567), and the 2017-2018 Belmont Forum and BiodivERsA joint call for research proposals (under the BiodivScen ERA-Net COFUND programme and with the funding organisations AEI, NWO, ECCyT and NSF).

\section{Data Availability Statement}

The data that support the findings of this study are available from the corresponding author upon reasonable request.

\section{References}

Albrecht, M., Kleijn, D., Williams, N.M., Tschumi, M., Blaauw, B.R., Bommarco, R., Campbell, A.J., Dainese, M., Drummond, F.A., Entling, M.H., Ganser, D., Arjen de Groot, G., Goulson, D., Grab, H., Hamilton, H., Herzog, F., Isaacs, R., Jacot, K., Jeanneret, P., Jonsson, M., Knop, E., Kremen, C., Landis, D.A., Loeb, G.M., Marini, L., McKerchar, M., Morandin, L., Pfister, S.C., Potts, S.G., Rundlöf, M., Sardiñas, H., Sciligo, A., Thies, C., Tscharntke, T., Venturini, E., Veromann, E., Vollhardt, I.M.G., Wäckers, F., Ward, K., Wilby, A., Woltz, M., Wratten, S. \& Sutter, L. (2020) The effectiveness of flower strips and hedgerows on pest control, pollination services and crop yield: a quantitative synthesis. Ecology Letters, 23, 1488-1498.

Amy, C., Noël, G., Hatt, S., Uyttenbroeck, R., Van de Meutter, F., Genoud, D. \& Francis, F. (2018) Flower strips in wheat intercropping system: effect on pollinator abundance and diversity in Belgium. Insects, 9, 114.

Bäckman, J.P.C. \& Tiainen, J. (2002) Habitat quality of field margins in a Finnish farmland area for bumblebees (Hymenoptera: Bombus and Psithyrus). Agriculture, Ecosystems \& Environment, 89, 53-68.

Balzan, M.V. (2017) Flowering banker plants for the delivery of multiple agroecosystem services. Arthropod-Plant Interactions, 11, 743-754.

Barbir, J., Badenes-Pérez, F.R., Fernández-Quintanilla, C. \& Dorado, J. (2015) Can floral field margins improve pollination and seed production in coriander Coriandrum sativum L. (Apiaceae)? Agricultural and Forest Entomology, 17, 302-308.

Bartomeus, I., Gagic, V. \& Bommarco, R. (2015) Pollinators, pests and soil properties interactively shape oilseed rape yield. Basic and Applied Ecology, 16, 737-745.

Begg, C.B. \& Mazumdar, M. (1994) Operating characteristics of a rank correlation test for publication bias. Biometrics, 50, 1088-1101.

Blaauw, B.R. \& Isaacs, R. (2014) Flower plantings increase wild bee abundance and the pollination services provided to a pollinationdependent crop. Journal of Applied Ecology, 51, 890-898.
Blake, R.J., Woodcock, B.A., Westbury, D.B., Sutton, P. \& Potts, S.G. (2011) New tools to boost butterfly habitat quality in existing grass buffer strips. Journal of Insect Conservation, 15, 221-232.

Borenstein, M., Hedges, L.V., Higgins, J.P. \& Rothstein, H.R. (2009) Introduction to Meta-Analysis. Chichester, UK: John Wiley \& Sons.

Boutin, C., Jobin, B., Bélanger, L. \& Choinière, L. (2002) Plant diversity in three types of hedgerows adjacent to cropfields. Biodiversity \& Conservation, 11, 1-25.

Buhk, C., Oppermann, R., Schanowski, A., Bleil, R., Lüdemann, J. \& Maus, C. (2018) Flower strip networks offer promising long term effects on pollinator species richness in intensively cultivated agricultural areas. BMC Ecology, 18, 55.

Burel, F. (1996) Hedgerows and their role in agricultural landscapes. Critical Reviews in Plant Sciences, 5, 169-190.

Campbell, A., Wilby, A., Sutton, P. \& Wäckers, F. (2017) Getting more power from your flowers: Multi-functional flower strips enhance pollinators and pest control agents in apple orchards. Insects, 8, 101.

Carreck, N.L. \& Williams, I.H. (1997) Observations on two commercial flower mixtures as food sources for beneficial insects in the UK. The Journal of Agricultural Science, 128, 397-403.

Carvell, C., Meek, W.R., Pywell, R.F. \& Nowakowski, M. (2004) The response of foraging bumblebees to successional change in newly created arable field margins. Biological Conservation, 118, 327-339.

Carvell, C., Osborne, J.L., Bourke, A.F.G., Freeman, S.N., Pywell, R. F. \& Heard, M.S. (2011) Bumble bee species' responses to a targeted conservation measure depend on landscape context and habitat quality. Ecological Applications, 21, 1760-1771.

Caudill, S.A., Brokaw, J.N., Doublet, D. \& Rice, R.A. (2017) Forest and trees: Shade management, forest proximity and pollinator communities in southern Costa Rica coffee agriculture. Renewable Agriculture and Food Systems, 32, 417-427.

Cheesman, O.D. (1998) The impact of some field boundary management practices on the development of Dipsacus fullonum L. flowering stems, and implications for conservation. Agriculture, Ecosystems \& Environment, 68, 41-49.

Croxton, P.J., Hann, J.P., Greatorex-Davies, J.N. \& Sparks, T.H. (2005) Linear hotspots? The floral and butterfly diversity of green lanes. Biological Conservation, 121, 579-584.

Dainese, M., Montecchiari, S., Sitzia, T., Sigura, M. \& Marini, L. (2017) High cover of hedgerows in the landscape supports multiple ecosystem services in Mediterranean cereal fields. Journal of Applied Ecology, 54, 380-388.

De Snoo, G.R., Van der Poll, R.J. \& Bertels, J. (1998) Butterflies in sprayed and unsprayed field margins. Journal of Applied Entomology, 122, 157-161.

Dover, J., Sparks, T., Clarke, S., Gobbett, K. \& Glossop, S. (2000) Linear features and butterflies: the importance of green lanes. Agriculture, Ecosystems, Environment, 80, 227-242.

Dover, J.W. (ed.) (2019) The Ecology of Hedgerows and Field Margins. London: Routledge.

Duru, M., Therond, O., Martin, G., Martin-Clouaire, R., Magne, M., Justes, E., Journet, E.P., Aubertot, J.N., Savary, S., Bergez, J.E. \& Sarthou, J.P. (2015) How to implement biodiversity-based agriculture to enhance ecosystem services: a review. Agronomy for Sustainable Development, 35, 1259-1281.

Feber, R.E., Smith, H. \& Macdonald, D.W. (1996) The effects on butterfly abundance of the management of uncropped edges of arable fields. Journal of Applied Ecology, 33, 1191-1205.

Feltham, H., Park, K., Minderman, J. \& Goulson, D. (2015) Experimental evidence that wildflower strips increase pollinator visits to crops. Ecology and Evolution, 5, 3523-3530.

Foley, J.A., DeFries, R., Asner, G.P., Barford, C., Bonan, G., Carpenter, S. R., Chapin, F.S., Coe, M.T., Daily, G.C., Gibbs, H.K., Helkowski, J.H., 
Holloway, T., Howard, E.A., Kucharik, C.J., Monfreda, C., Patz, J.A., Prentice, I.C., Ramankutty, N. \& Snyder, P.K. (2005) Global consequences of land use. Science, 309, 570-574.

Fussell, M. \& Corbet, S.A. (1992) Flower usage by bumble-bees: a basis for forage plant management. Journal of Applied Ecology, 29, 451-465.

Gagic, V., Kleijn, D., Báldi, A., Boros, G., Jørgensen, H.B., Elek, Z., Garratt, M.P.D., Groot, d., Arjen, G., Hedlund, K., KovácsHostyánszki, A., Marini, L., Martin, E., Pevere, I., Potts, S.G., Redlich, S., Senapathi, D., Steffan-Dewenter, I., Đwitek, S., Smith, H. G., Takács, V., Tryjanowski, P., van der Putten, W.H., van Gils, S. \& Bommarco, R. (2017) Combined effects of agrochemicals and ecosystem services on crop yield across Europe. Ecology Letters, 20, 1427-1436.

Ganser, D., Mayr, B., Albrecht, M. \& Knop, E. (2018) Wildflower strips enhance pollination in adjacent strawberry crops at the small scale. Ecology and Evolution, 8, 11775-11784.

Garibaldi, L.A., Aizen, M.A., Cunningham, S. \& Klein, A.M. (2009) Pollinator shortage and global crop yield: looking at the whole spectrum of pollinator dependency. Communicative \& Integrative Biology, 2, 37-39.

Garibaldi, L.A., Carvalheiro, L.G., Leonhardt, S.D., Aizen, M., Blaauw, B.R., Isaacs, R., Kuhlmann, M., Kleijn, D., Klein, A.M., Kremen, C., Morandin, L., Scheper, J. \& Winfree, R. (2014) From research to action: enhancing crop yield through wild pollinators. Frontiers in Ecology and the Environment, 12, 439-447.

Garratt, M.P., Senapathi, D., Coston, D.J., Mortimer, S.R. \& Potts, S.G. (2017) The benefits of hedgerows for pollinators and natural enemies depends on hedge quality and landscape context. Agriculture, Ecosystems \& Environment, 247, 363-370.

Goulson, D., Nicholls, E., Botías, C. \& Rotheray, E.L. (2015) Bee declines driven by combined stress from parasites, pesticides, and lack of flowers. Science, 347, 1255957.

Greenleaf, S.S. \& Kremen, C. (2006) Wild bees enhance honey bees pollination of hybrid sunflower. Proceedings of the National Academy of Sciences, 103, 13890-13895.

Haenke, S., Kovács-Hostyánszki, A., Fründ, J., Batáry, P., Jauker, B., Tscharntke, T. \& Holzschuh, A. (2014) Landscape configuration of crops and hedgerows drives local syrphid fly abundance. Journal of Applied Ecology, 51, 505-513.

Haenke, S., Scheid, B., Schaefer, M., Tscharntke, T. \& Thies, C. (2009) Increasing syrphid fly diversity and density in sown flower strips within simple vs. complex landscapes. Journal of Applied Ecology, 46, 1106-1114.

Hannon, L.E. \& Sisk, T.D. (2009) Hedgerows in an agri-natural landscape: potential habitat value for native bees. Biological Conservation, 142, 2140-2154.

Hedges, L.V. \& Olkin, I. (1985) Statistical Methods for Meta-analysis. Academic Press, Orlando, FL.

Hinsley, S.A. \& Bellamy, P.E. (2000) The influence of hedge structure, management, and landscape context on the value of hedgerows to birds: a review. Journal of Environmental Management, 60, 33-49.

Holzschuh, A., Steffan-Dewenter, I. \& Tscharntke, T. (2010) How do landscape composition and configuration, organic farming and fallow strips affect the diversity of bees, wasps and their parasitoids? Journal of Animal Ecology, 79, 491-500.

Kleijn, D., Baquero, R.A., Clough, Y., Díaz, M., De Esteban, J., Fernández, F., Gabriel, D., Herzog, F., Holzschuh, A., Jöhl, R., Knop, E., Kruess, A., Marshall, E.J., Steffan-Dewenter, I., Tscharntke, T., Verhulst, J., West, T.M. \& Yela, J.L. (2006) Mixed biodiversity benefits of agri-environment schemes in five European countries. Ecology Letters, 9, 243-254.

Klein, A.M., Brittain, C., Hendrix, S.D., Thorp, R., Williams, N. \& Kremen, C. (2012) Wild pollination services to California almond rely on semi-natural habitat. Journal of Applied Ecology, 49, 723-732.

Kleijn, D., Linders, T.E., Stip, A., Biesmeijer, J.C., Wäckers, F.L. \& Bukovinszky, T. (2018) Scaling up effects of measures mitigating pollinator loss from local-to landscape-level population responses. Methods in Ecology and Evolution, 9, 1727-1738.

Knapp, J.L., Shaw, R.F. \& Osborne, J.L. (2019) Pollinator visitation to mass-flowering courgette and co-flowering wild flowers: implications for pollination and bee conservation on farms. Basic and Applied Ecology, 34, 85-94.

Koricheva, J., Gurecitch, J. \& Mengersen, K. (eds) (2013) The Handbook of Meta-Analysis in Ecology and Evolution. Princeton University Press, Princeton and Oxford.

Kort, J., Collins, M. \& Ditsch, D. (1998) A review of soil erosion potential associated with biomass crops. Biomass and Bioenergy, 14, 351-359.

Kremen, C., Albrech, M. \& Ponisio, L.C. (2019) Restoring pollinator communities and pollination services in hedgerows in intensivelymanaged agricultural landscapes. The Ecology of Hedgerows and Field Margins (ed. by J.W. Dover), p. 163. London: Routledge.

Kremen, C. \& Miles, A. (2012) Ecosystem services in biologically diversified versus conventional farming systems: benefits, externalities, and trade-offs. Ecology and Society, 17, 40.

Kremen, C., Williams, N.M., Bugg, R.L., Fay, J.P. \& Thorp, R.W. (2004) The area requirements of an ecosystem service: crop pollination by native bee communities in California. Ecology Letters, 7, 1109-1119.

Kremen, C., Williams, N.M., Aizen, M.A., Gemmill-Herren, B., LeBuhn, G., Minckley, R., Packer, L., Potts, S.G., Roulston, T., Steffan-Dewenter, I., Vazquez, D.P., Winfree, R., Adams, L., Crone, E.E., Greenleaf, S.S., Keitt, T.H., Klein, A.M., Regetz, J. \& Ricketts, T.H. (2007) Pollination and other ecosystem services produced by mobile organisms: a conceptual framework for the effects of land-use change. Ecology Letters, 10, 299-314.

Lagerlöf, J., Stark, J. \& Svensson, B. (1992) Margins of agricultural fields as habitats for pollinating insects. Agriculture, Ecosystems \& Environment, 40, 117-124.

Long, R.F. \& Anderson, J. (2010) Establishing Hedgerows on Field Crop Farms in California's Central Valley. UC ANR Pub, 8390.

Lye, G., Park, K., Osborne, J., Holland, J. \& Goulson, D. (2009) Assessing the value of Rural Stewardship schemes for providing foraging resources and nesting habitat for bumblebee queens (Hymenoptera: Apidae). Biological Conservation, 142, 2023-2032.

Mader, E., Shepherd, M., Vaughan, M., Black, S.H. \& LeBuhn, G. (2011) Attracting Native Pollinators: Protecting North America's Bees and Butterflies, p. 371. North Adams, MA: Storey Publishing.

Marshall, E.J.P. \& Moonen, A.C. (2002) Field margins in northern Europe: their functions and interactions with agriculture. Agriculture, Ecosystems \& Environment, 89, 5-21.

Maudsley, M.J. (2000) A review of the ecology and conservation of hedgerow invertebrates in Britain. Journal of Environmental Management, 60, 65-76.

McKechnie, I.M., Thomsen, C.J. \& Sargent, R.D. (2017) Forested field edges support a greater diversity of wild pollinators in lowbush blueberry (Vaccinium angustifolium). Agriculture, Ecosystems \& Environment, 237, 154-161.

M'Gonigle, L.K., Ponisio, L.C., Cutler, K. \& Kremen, C. (2015) Habitat restoration promotes pollinator persistence and colonization in intensively managed agriculture. Ecological Applications, 25, 1557-1565.

Merckx, T., Feber, R.E., Riordan, P., Townsend, M.C., Bourn, N.A., Parsons, M.S. \& Macdonald, D.W. (2009) Optimizing the biodiversity gain from agri-environment schemes. Agriculture, Ecosystems \& Environment, 130, 177-182. 
Morandin, L.A. \& Kremen, C. (2013a) Bee preference for native versus exotic plants in restored agricultural hedgerows. Restoration Ecology, 21, 26-32.

Morandin, L.A. \& Kremen, C. (2013b) Hedgerow restoration promotes pollinator populations and exports native bees to adjacent fields. Ecological Applications, 23, 829-839.

Morandin, L.A., Long, R.F. \& Kremen, C. (2016) Pest control and pollination cost-benefit analysis of hedgerow restoration in a simplified agricultural landscape. Journal of Economic Entomology, 109, 1020-1027.

Mwangi, D., Kasina, M., Nderitu, J., Hagen, M., Gikungu, M. \& Kraemer, M. (2012) Diversity and abundance of native bees foraging on hedgerow plants in the Kakamega farmlands, western Kenya. Journal of Apicultural Research, 51, 298-305.

Oliver, T.H., Heard, M.S., Isaac, N.J.B., Roy, D.B., Procter, D., Eigenbrod, F., Freckleton, R., Hector, A., Orme, C.D.L., Petchey, O. L., Proença, V., Raffaelli, D., Suttle, K.B., Mace, G.M., MartínLópez, B., Woodcock, B.A. \& Bullock, J.M. (2015) Biodiversity and resilience of ecosystem functions. Trends in Ecology \& Evolution, 30, 673-684.

Pfiffner, L., Ostermaier, M., Stoeckli, S. \& Müller, A. (2018) Wild bees respond complementarily to 'high-quality' perennial and annual habitats of organic farms in a complex landscape. Journal of Insect Conservation, 22, 551-562.

Potts, S.G., Woodcock, B.A., Roberts, S.P.M., Tscheulin, T., Pilgrim, E. S., Brown, V.K. \& Tallowin, J.R. (2009) Enhancing pollinator biodiversity in intensive grasslands. Journal of Applied Ecology, 46, 369-379.

Prys-Jones, O.E. \& Corbet, S.A. (1991) Naturalists' Handbooks 6: Bumblebees. Richmond Publishing Co. Ltd., Slough.

Pywell, R.F., Warman, E.A., Carvell, C., Sparks, T.H., Dicks, L.V., Bennett, D., Wright, A., Critchley, C.N.R. \& Sherwood, A. (2005) Providing foraging resources for bumblebees in intensively farmed landscapes. Biological Conservation, 121, 479-494.

Pywell, R.F., Warman, E.A., Hulmes, L., Hulmes, S., Nuttall, P., Sparks, T.H., Critchley, C.N.R. \& Sherwood, A. (2006) Effectiveness of new agri-environment schemes in providing foraging resources for bumblebees in intensively farmed landscapes. Biological Conservation, 129, 192-206.

Pywell, R.F., Heard, M.S., Woodcock, B.A., Hinsley, S., Ridding, L., Nowakowski, M. \& Bullock, J.M. (2015) Wildlife-friendly farming increases crop yield: evidence for ecological intensification. Proceedings of the Royal Society B: Biological Sciences, 282, 20151740.

Pywell, R.F., Meek, W.R., Hulmes, L., Hulmes, S., James, K.L., Nowakowski, M. \& Carvell, C. (2011a) Management to enhance pollen and nectar resources for bumblebees and butterflies within intensively farmed landscapes. Journal of Insect Conservation, $\mathbf{1 5}$, 853-864.

Pywell, R.F., Meek, W.R., Loxton, R.G., Nowakowski, M., Carvell, C. \& Woodcock, B.A. (2011b) Ecological restoration on farmland can drive beneficial functional responses in plant and invertebrate communities. Agriculture, Ecosystems \& Environment, 140, 62-67.

Ramankutty, N., Evan, A.T., Monfreda, C. \& Foley, J.A. (2008) Farming the planet: 1. Geographic distribution of global agricultural lands in the year 2000. Global biogeochemical Cycles, 22, GB1003.

R Development Core Team (2018) R: A Language and Environment for Statistical Computing. R Foundation for Statistical Computing, Vienna, Austria Retrieved from http://www.R-project.org.

Rundlöf, M., Lundin, O. \& Bommarco, R. (2018) Annual flower strips support pollinators and potentially enhance red clover seed yield. Ecology and Evolution, 8, 7974-7985.
Sardiñas, H.S. \& Kremen, C. (2015) Pollination services from field-scale agricultural diversification may be context-dependent. Agriculture, Ecosystems \& Environment, 207, 17-25.

Sardiñas, H.S., Tom, K., Ponisio, L.C., Rominger, A. \& Kremen, C. (2016) Sunflower (Helianthus annuus) pollination in California's Central Valley is limited by native bee nest site location. Ecological Applications, 26, 438-447.

Scheper, J., Holzschuh, A., Kuussaari, M., Potts, S.G., Rundlöf, M., Smith, H.G. \& Kleijn, D. (2013) Environmental factors driving the effectiveness of European agri-environmental measures in mitigating pollinator loss-a meta-analysis. Ecology Letters, 16, 912-920.

Scheper, J., Bommarco, R., Holzschuh, A., Potts, S.G., Riedinger, V., Roberts, S.P.M., Rundlöf, M., Smith, H.G., Steffan-Dewenter, I., Wickens, J.B., Wickens, V.J. \& Kleijn, D. (2015) Local and landscape-level floral resources explain effects of wildflower strips on wild bees across four European countries. Journal of Applied Ecology, 52, 1165-1175.

Smith, J., Potts, S.G., Woodcock, B.A. \& Eggleton, P. (2008) Can arable field margins be managed to enhance their biodiversity, conservation and functional value for soil macrofauna? Journal of Applied Ecology, 45, 269-278.

Sutter, L., Albrecht, M. \& Jeanneret, P. (2018) Landscape greening and local creation of wildflower strips and hedgerows promote multiple ecosystem services. Journal of Applied Ecology, 55, 612-620.

Tangtorwongsakul, P., Warrit, N. \& Gale, G.A. (2018) Effects of landscape cover and local habitat characteristics on visiting bees in tropical orchards. Agricultural and Forest Entomology, 20, 28-40.

Tilman, D., Fargione, J., Wolff, B., D'Antonio, C., Dobson, A., Howarth, R., Schindler, D., Schlesinger, W.H., Simberloff, D. \& Swackhamer, D. (2001) Forecasting agriculturally driven global environmental change. Science, 292, 281-284.

Tscharntke, T., Klein, A.M., Kruess, A., Steffan-Dewenter, I. \& Thies, C. (2005) Landscape perspectives on agricultural intensification and biodiversity-ecosystem service management. Ecology Letters, 8, 857-874.

Venturini, E.M., Drummond, F.A., Hoshide, A.K., Dibble, A.C. \& Stack, L.B. (2017) Pollination reservoirs in lowbush blueberry (Ericales: Ericaceae). Journal of Economic Entomology, 110, 333-346.

Viechtbauer, W. (2010) Conducting meta-analyses in R with the metafor package. Journal of Statistical Software, 36, 1-48.

Walton, N.J. \& Isaacs, R. (2011) Influence of native flowering plant strips on natural enemies and herbivores in adjacent blueberry fields. Environmental Entomology, 40, 697-705.

Whitehouse, T.S., Sial, A.A. \& Schmidt, J.M. (2018) Natural enemy abundance in Southeastern blueberry agroecosystems: distance to edge and impact of management practices. Environmental Entomology, 47, 32-38.

Williams, N.M., Minckley, R.L. \& Silveira, F.A. (2001) Variation in native bee faunas and its implications for detecting community changes. Conservation Ecology, 5, 57-89.

Williams, N.M., Ward, K.L., Pope, N., Isaacs, R., Wilson, J., May, E.A., Ellis, J., Daniels, J., Pence, A., Ullmann, K. \& Peters, J. (2015) Native wildflower plantings support wild bee abundance and diversity in agricultural landscapes across the United States. Ecological Applications, 25, 2119-2131.

Winfree, R. (2010) The conservation and restoration of wild bees. Annals of the New York Academy of Sciences, 1195, 169-197.

Winfree, R., Williams, N.M., Gaines, H., Ascher, J.S. \& Kremen, C. (2008) Wild bee pollinators provide the majority of crop visitation across land-use gradients in New Jersey and Pennsylvania, USA. Journal of Applied Ecology, 45, 793-802. 
Wood, T.J., Gibbs, J., Rothwell, N., Wilson, J.K., Gut, L., Brokaw, J. \& Isaacs, R. (2018) Limited phenological and dietary overlap between bee communities in spring flowering crops and herbaceous enhancements. Ecological Applications, 28, 1924-1934.

Wratten, S.D., Gillespie, M., Decourtye, A., Mader, E. \& Desneux, N. (2012) Pollinator habitat enhancement: benefits to other ecosystem services. Agriculture, Ecosystems \& Environment, 159 $112-122$.

Accepted 20 September 2020

Editor: Raphael Didham; Associate Editor: Michael Garratt 